\title{
Introduction to this international research issue
}

\author{
Gary R. Morrison
}

Published online: 15 July 2014

(C) Springer Science+Business Media New York 2014

Last fall, we received a large number of submissions from international authors. To help us expedite the process, I asked several individuals to provide an extended review of selected manuscripts and offer detailed feedback to help the authors revise their submissions. We did not select every manuscript for publication, but I would like to thank the following individuals for providing detailed reviews for this issue.

The list of reviewers included the following.

Jan L. Plass

Michael Maurice Grant

Shahron G Williams van Rooij

Barbara Grabowski

Delia Neuman

Bob Bernard

Yauz Akbulat

Trena M. Paulus

Irina Elgort

James Quinn

Wilson, Brent

Chuck Hodges

Vance Durrington

G. R. Morrison ( $\square)$

Norfolk, VA, USA

e-mail: gmorriso@odu.edu 